\title{
" Sistem Informasi Dashboard Monitoring Untuk Pengorderan Barang Dan Jasa Pada PT Energi Listrik Batam “
}

\author{
M.Ropianto*1, Okta Veza ${ }^{2}$, Mc Donald ${ }^{3}$ \\ Program Studi Teknik Informatika, STT Ibnu Sina, Batam \\ E-mail: ${ }^{1}$ Ropianto@ stt-ibnusina.ac.id, ${ }^{2}$ Okta@ stt-ibnusina.ac.id, ${ }^{3}$ mcdonald78@ outlook.com
}

\begin{abstract}
Abstrak
PT Energi Listrik Batam merupakan perusahaan yang bergerak dibidang supply energy listrik. Pada perusahaan tersebut terdapat bagian yang menangani pengadaan barang dan jasa, keadaan pengolahan permintaan barang dan jasa yang terjadi masih dilakukan dengan manual form sehingga banyaknya kendala yang terjadi dilapangan seperti jarak antar devisi yang lumayan jauh memakan waktu untuk pengambilan form permintaan barang tersebut. Keadaan kurangnya pendataan dan tidak adanya aplikasi pendukung serta data yang masih disimpan dalam bentuk arsip maupun secara manual mengakibatkan lambatnya proses pengadaan barang. Sistem Informasi Monitoring Dashboard Untuk Pengorderan Barang Dan Jasa Pada PT Energi Listrik Batam ini merupakan aplikasi pendukung kinerja pihak istansi terkait. Sistem aplikasi ini Dirancang berbasis web dengan menggunakan model Sistem Development Life Cycle (SDLC) dan untuk menampilkan data dalam bentuk grafik digunakan model dashboard untuk lebih mempermudah dalam menampilkan jumlah data yang ada. Sistem Informasi ini berfungsi sebagai sarana pengajuan permintaan barang secara online dari operator kepada pimpinan. Dengan adanya sistem informasi ini diharapkan bagi pihak instansi akan lebih mudah dalam pengajuan permintaan barang, serta pembuatan laporan bulanan mengenai grafik permintaan barang
\end{abstract}

Kata kunci : Operator, Pimpinan, Dashboard, PT Energi Listrik Batam.

\begin{abstract}
PT Energi Listrik Batam is a company engaged in the supply of electrical energy. In the company there are parts that handle the procurement of goods and services, the condition of processing demand for goods and services that occur is still done with manual form so that many obstacles that occur in the field such as distance between the division is quite far to take time to take the form of demand for the goods. The condition of the lack of data collection and the absence of supporting applications and data that are still stored in the form of archives or manually result in slow procurement process. Dashboard Monitoring Information System For Charging Goods And Services At PT Energi Listrik Batam is an application supporting performance related parties istansi. This application system Designed web-based using the System Development Life Cycle (SDLC) model and to display data in graphical form used dashboard model to further facilitate in displaying the amount of data available. This Information System serves as a means of submitting online goods demand from the operator to the leadership. With this information system is expected for the agency will be easier in the submission of goods demand, as well as making monthly reports on the demand graph of goods
\end{abstract}

Keywords : Operator, Leader, Dashboard, PT Energi Listrik Batam. 


\section{PENDAHULUAN}

$P$ ada era modern saat ini teknologi informasi komputer sudah sangat maju. Pada perkembangan teknologi informasi yang maju ini, semua orang dapat dengan mudah mengakses berbagai informasi dengan cepat walau dari dari jarak yang sangat jauh. Informasi dari luar negeri sekalipun dapat dengan mudah dan cepat kita akses melalui internet. Dan Teknologi Informasi komputer sekarang ini sudah sangat canggih, sehingga bisa digunakan untuk mengakses informasi maupun situs jejaring sosial. Karena perkembangan itulah, sekarang ini banyak perusahaan yang menggunakan teknologi informasi untuk bisnis. Untuk meningkatkan keunggulan daya saing bisnis dalam era yang sangat kompetitif ini tidak dapat di hindari lagi bahwa kebutuhan akan teknologi sangat dibutuhkan. Tanpa daya saing yang tinggi, di era sekarang ini akan susah sebuah perusahaan akan bertahan, apalagi memenangkan persaingan. Pengetahuan tentang teknologi informasi, sekarang ini sangatlah penting untuk pengusaha. Organisasi seringkali dihadapkan pada perubahan lingkungan bisnis yang cepat. Berkaitan dengan hal tersebut, maka organisasi perlu melakukan monitoring dan pengukuran secara berkelanjutan terhadap kinerja organisasi untuk memastikan ketercapaian tujuan yang telah ditetapkan. Proses monitoring kinerja memerlukan data dan informasi yang diambil dari seluruh bagian organisasi. Hasil monitoring kinerja diharapkan dapat disampaikan kepada pihak-pihak yang berkepentingan pada waktu yang tepat (Hakim, 2012). Begitu juga dengan sistem informasi yang sudah banyak digunakan hampir diseluruh instansi baik pemerintah maupun swasta, salah satunya perusahaan di bidang supply Listrik di Kota Batam yaitu PT Energi Listrik Batam, PT Energi Listrik Batam ini mulai beroperasional tahuna 2015 dengan menggunakan Gas sebagai sumber daya untuk meghasilkan listrik, PT Energi Listrik Batam sudah mampu mendukung kelancaran dalam pemberian tenaga listrik di Kepulauan Riau khususnya, PT Energi Listrik batam memeliki bebererapa divisi yaitu divisi operasional, divisi keuangan dan divisi warehouse yang semuanya masih dalam tahap pengembangan dan belum saling terintegrasi dalam hal penyajian sistem informasi, untuk sistem informasinya maka dari itu dalam hal ini penulis berkeinginan meneliti sistem informasi yang selama ini digunakan di perusahaan pembangkit listrik Sistem Informasi merupakan suatu sistem informasi belum terintegarasi. Setiap harinya, kegiatan yang ada di perusahaan tersebut tiap divisi jika ingin melakukan permintaan pembelian dan order barang dan jasa ke bagian departemen pembelian masih menggunakan dalam bentuk manual yang sederhana dan tidak dalam bentuk suatu sistem aplikasi yang menunjang, adapun dalam meminta persetujuan kebagian level top manajemen juga tidak efisien dalam permintaaan barang dan jasa, ketika ada suatu permintaan tiap divisi harus mengisi suatu form manual yang sudah di siapkan dari bagian pembelian dan secara manual user harus menuju ke bagian yang berwewenang untuk meminta persetujuan atau untuk di tandatangani membutuhkan waktu yang tidak efisien dan dalam pengolahan data dan penyimpanan data juga masih manual sehingga untuk memonitor sejauh mana permintaan pembelian tersebut tidak bisa secara optimal sehinga jika pimpinan akan melakukan pengontrolan suatu bagian atau akan sulit mengetahui secara keseluruhan kegiatan perusahaan tersebut secara akurat, relevan dan real time.

\section{METODE PENELITIAN}

Metode pengumpulan data yang dilakukan adalah metode Deskriptif dimana pengumpulan data yang dilakukan untuk menghasilkan data dan informasi yang diperlukan serta berhubungan dengan hal yang penulis lakukan. Untuk mengumpulkan data serta informasi yang diperlukan oleh penulis menggunakan metode sebagai berikut:

1. Studi pustaka

Studi pustaka merupakan suatu tehnik pengumpulan data dengan menghimpun dan menganalisis dokumen-dokumen, baik dokumen tertulis, gambar, maupun elektronik. 
penelitian ini dilakukan diperpustakaan STT Ibnu Sina Batam dan di PT Eenergi Listrik Batam.

2. Studi literatur

Studi literatur adalah mencari referensi teori yang relefan dengan kasus atau permasalahan yang di temukan, referensi ini dapat di cari di buku-buku, jurnal, internet.

3. Studi Lapangan

Studi Lapangan ( Field Research) adalah pengumpulan data secara langsung ke lapangan dengan mempergunakan teknik pengumpulan data sebagai berikut:
a. Observasi
mengadakan pengamatan terhadap obyek yang diteliti. Observasi dilakukan untuk memperoleh informasi tentang flow pengorderan barang dan jasa
b. Wawancara
Wawancara adalah teknik penelitian yang paling sosiologis karena bentuknya yang berasal dari interaksi verbal antara peneliti dan responden dan juga cara yang paling baik untuk mendapatkan sebuah informasi.
c. Studi Dokumentasi
Dokumentasi adalah merupakan sejumlah bahan bukti yang terekam/tercatat yang memperlihatkan karakteristik-karakteristik dari sebagian atau semua dari suatu sistem manajemen, termasuk di dalamnya, seluruh berkas bahan bukti tentang pilihan-pilihan ataupun keputusan-keputusan yang pernah dibuat sebelumnya selama pengkajian suatu sistem

\subsection{Metode Pengolahan data}

Metode pengolahan data yang digunakan dalam penelitian ini adalah sebagai berikut:

1. Analisa sistem yang sedang berjalan

2. Analisa dan usulan sistem yang baru

3. Data Flow Diagram (DFD)

4. Perancangan Output

5. Perancangan Input

6. Perancangan database

7. Entity Relationship Diagram (ERD)

8. Pengujian dan perbaikan sistem

9. Penyajian dalam bentuk Dashboard 
2. 1 Kerangka Pemecahan masalah

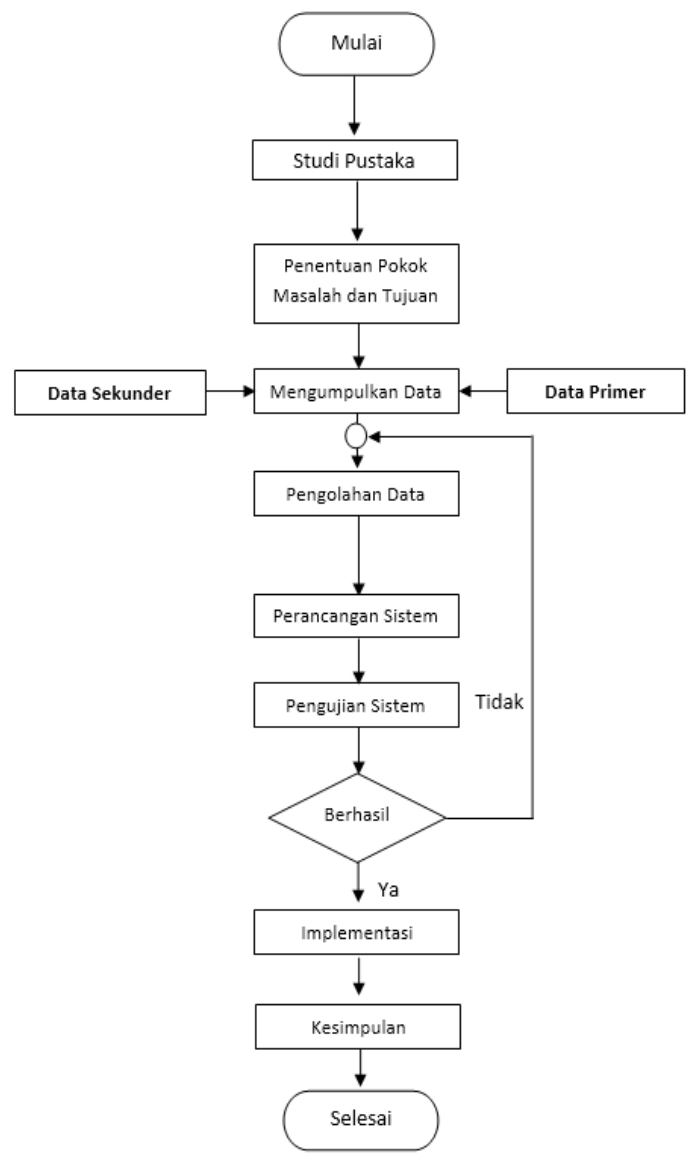

\section{2 Tahap pengolahan data}

Adapun tahapan yang penulis lakukan adalah sebagai berikut:

\section{Identifikasi masalah}

Mengidentifikasi masalah-masalah yang terjadi selama ini di khususnya dalam pengelolahan penginputan biodata mahasiswa.

\section{Analisa sistem}

Adapun tahapan-tahapan analisa sistem yang penulis lakukan adalah :

a) Membangun aliran sistem informasi yang sedang berjalan, mengevaluasi pada sistem yang ada, setelah mengevaluasi sistem informasi yang lama, selanjutnya penulis akan merancang perbaikan pada sistem dan menyusun aliran sistem informasi yang baru.

b) Menganalisa data primer dan sekunder dan akan digunakan pada sistem yang sedang berjalan.

c) Penulis akan mempelajari spesifikasi masukan dan keluaran pada sistem informasi yang berjalan untuk dipergunakan sebagai bahan dalam menyusun perangkat sistem yang akan diterapkan. 


\section{3 Analisa dan sistem desain}

\subsubsection{Analisa Sistem}

Pada tahap analisa sistem, penulis akan melakukan tahapan analisis dan evaluasi antara lain :

1. Mempelajari aliran informasi dari setiap bagian yang ada dalam PT Energi Listrik Batam, serta organisasi atau bagian lainnya yang yang terlibat didalam kegiatan pengorderan barang dan jasa untuk digunakan sebagai bahan analisi dan evaluasi dalam menyusun struktur data

2. Mempelajari spesifikasi masukan data dan keluaran informasi dari setiap bagian serta penyebaran data dan pemakaian informasi tersebut

3. Mempelajari format masukan dan format keluaran. dan tata cara penyajian informasi serta hal-hal yang berhubungan dengan administrasi informasi untuk dipergunakan sebagai bahan dalam menyusun perangkat sistem yang akan diterapkan

4. Mempelajari peluang untuk perluasan dan pengembangan aspek informasi yang diolah (dalam bentuk grafis, diagram dan tabel) maupun yang akan disimpan serta kendala yang dapat mempengaruhinya.

\section{3.2 Desain Sistem}

Pada tahap selanjutnya penulis akan melakukan tahap desain sistem untuk merancang sistem yang baru. dalam tahapan ini perlu dilakukan langkah-langkah sebagai berikut:

1. Mempelajari dan mengumpulkan data untuk disusun menjadi sebuah struktur data yang teratur sesuai dengan sistem yang akan dibuat.

2. Melakukan evaluasi serta merumuskan dari masing-masing bentuk informasi yang akan disajikan.

3. Menganalisis kendala yang akan dihadapi dari permasalahan yang mungkin timbul dalam proses perancangan sistem.

4. Menyusun kriteria tampilan informasi yang akan dihasilkan secara keseluruhan, sehingga dapat memudahkan dalam hal indetifikasi, analisi, dan evaluasi terhadap aspek yang ada dalam permasalah Sistem media informasi, Pengelolahan penginputan pengorderan barang dan jasa di PT Energi Listrik Batam.

\section{4 Analisa dan kebutuhan sistem}

Untuk dapat menangani isu-isu yang terdapat dari analisis PIECES di atas berikut ini akan ditentukan kebutuhan sistemnya secara lengkap. Dalam sub bab ini akan terbagi menjadi dua jenis kebutuhan sistem yaitu perangkat lunak (software) kebutuhan fungsional (functional requirement) dan kebutuhan nonfungsional (nonfunctional requirement)

\section{HASIL DAN PEMBAHASAN}

Penelitian dan pengumpulan data pada sistem yang berjalan dengan tujuan mendapatkan data secara lengkap untuk dapat merancang sistem yang baru atau sistem yang akan diperbaharui dari sistem yang sedang berjalan. Dengan data yang diperoleh maka akan dapat diimplementasikan pada sistem yang nantinya akan dibuat.

\section{1 Aliran sistem informasi}

Data yang penulis kumpulkan, selanjutnya akan diolah agar bisa digunakan untuk sistem baru yang telah direncanakan, dan digambarkan dengan tahapan aliran sistem informasi yang berjalan, dan memberikan usulan pada aliran sistem informasi yang baru. 


\section{1.1 Aliran sistem informasi lama}

Pada Aliran Sistem Informasi Lama (ASI Lama) semua kegiatan yang berhubungan dengan data permintaan barang di PT Energi Listrik Batam masih dilakukan secara manual. Penggambaran dari Aliran Sistem Informasi Lama (ASI Lama) dapat dilihat pada gambar dibawah ini:

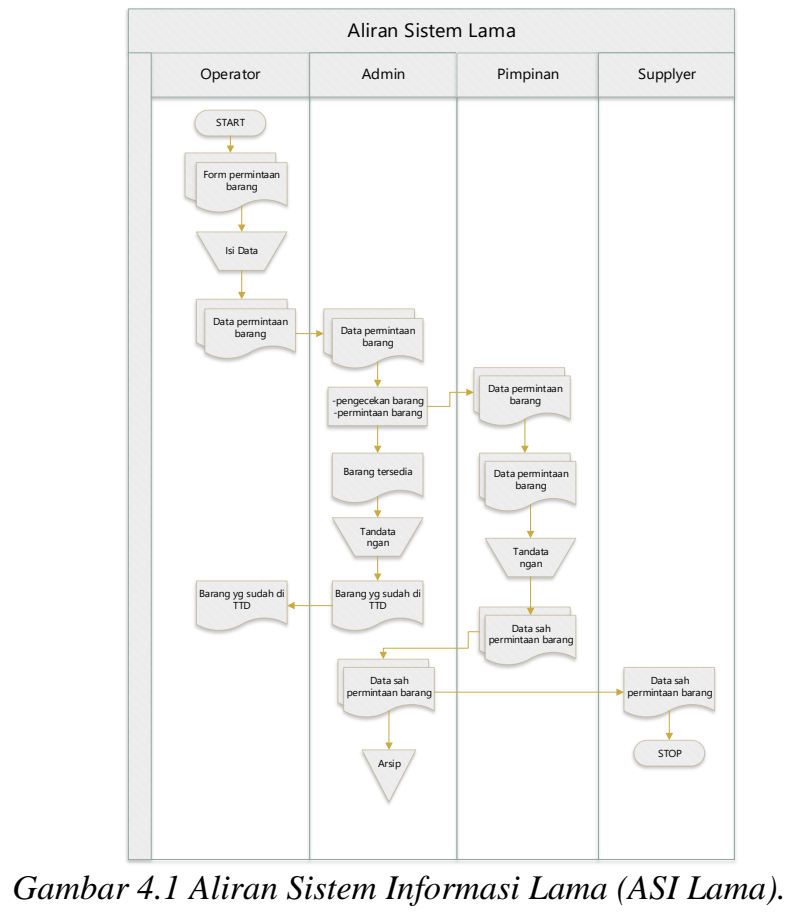

\section{1.2 Aliran sistem informasi yang diusulkan}

Aliran sistem informasi yang baru adalah merupakan perbaikan dari sistem yang lama, dimana sistem yang pada awalnya manual atau semi komputer menjadi terkomputerisasi atau berbasis database. Antara aliran sistem informasi lama dan aliran sistem informasi baru tidak begitu banyak terjadi perubahan. Perubahan terjadi hanya pada proses penyimpanan dan pengolahan data. Untuk lebih jelasnya dapat dilihat pada gambar dibawah ini :

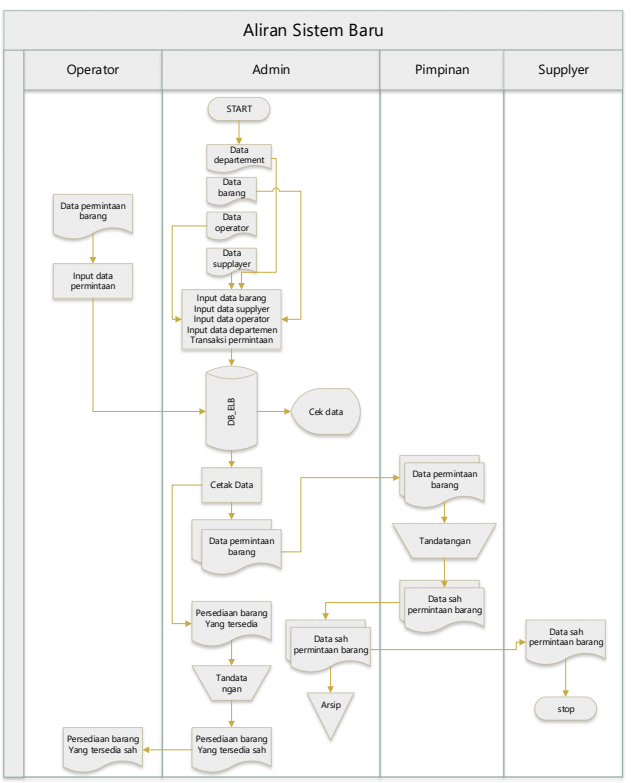

Gambar 3.1.3 Aliran Sistem Informasi yang diusulkan 


\section{1.3 Analisa kebutuhan sistem}

Berdasarkan Aliran Sistem Informasi Lama (ASI Lama) dapat disimpulkan bahwa dibutuhkan beberapa fitur untuk memenuhi kebutuhan sistem pada PT Energi Listrik Batam, fitur-fitur tersebut dapat dilihat pada tabel dibawah ini.

Tabel.1.0 Kebutuhan sistem

\begin{tabular}{|c|c|c|}
\hline No & Jenis Fitur & Keterangan \\
\hline 1 & Login & $\begin{array}{l}\text { Terdapat } 3 \text { tampilan login yaitu } \\
\text { admin, operator dan administrator. }\end{array}$ \\
\hline 2 & Admin & $\begin{array}{l}\text { Bertugas untuk melakukan } \\
\text { penambahan, merubah, menghapus, } \\
\text { data permintaan dan mencetak data } \\
\text { permintaan, meng menyetujui } \\
\text { permintaan barang dari operator. } \\
\text { Admin juga dapat menambah data } \\
\text { barang, data suplayer dan data } \\
\text { operator serta mencetak data barang }\end{array}$ \\
\hline 3 & Operator & Menginputkan data permintaan \\
\hline 4 & Administratror & $\begin{array}{l}\text { Bertugas menambahkan menu dan } \\
\text { user login. }\end{array}$ \\
\hline
\end{tabular}

\subsubsection{Perancangan sistem}

Perancangan system merupakan tahapan selanjutnya setelah menganalisa sistem yang ada serta mendapatkan gambaran dengan jelas tentang apa yang akan dikerjakan. Untuk mencapai harapan pembuatan sistem informasi di PT Energi Listrik Batam, rancangan sistem informasi ini akan digambarkan menggunakan data flow diagram, rancangan database dan relasi database.

\section{Diagram Context}

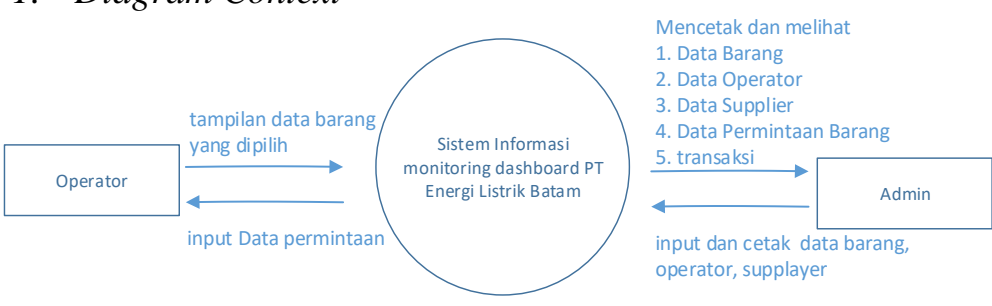

2. DFD Level 0

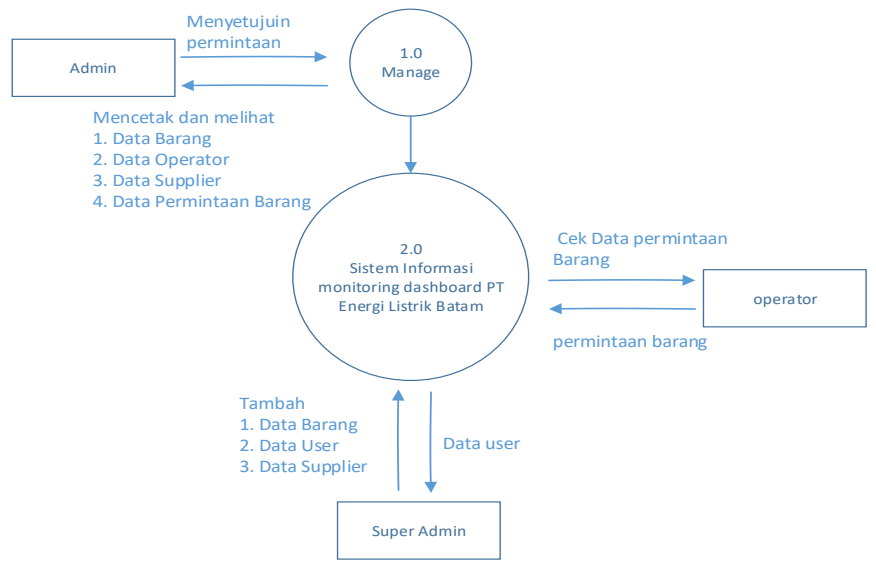




\section{DFD Level 1}
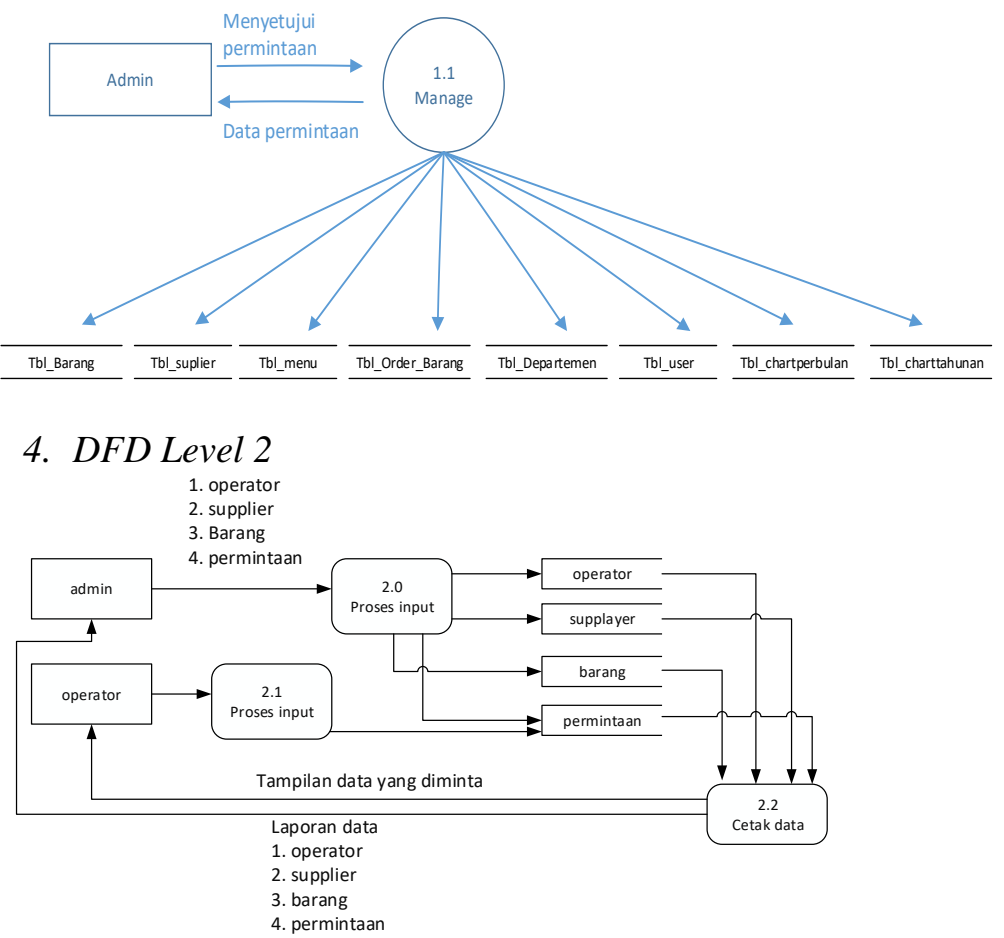

\subsubsection{Relasi table}

Adalah gambaran alur ketersambungan antar tabel satu dengan tabel yang lain yang biasa di sebut Entity-Relationship Diagrams (ERD), adapun gambarannya adalah sebagai berikut:
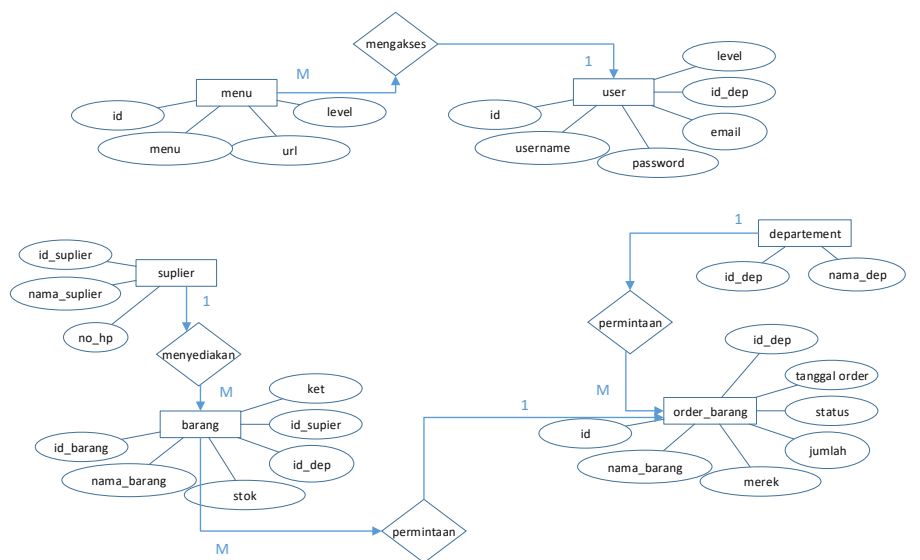

\subsubsection{Perancangan Database}

Adapun tabel-tabel yang terdapat dalam Sistem Informasi Monitoring Dashboard Untuk Pengordera Barang Dan Jasa Pada PT Energi Listrik Batam yang terdapat dalam database db_ELB adalah sebagai berikut:

Tabel 2 .0 db_ELB

\begin{tabular}{|c|l|}
\hline No & \multicolumn{1}{|c|}{ Nama Tabel } \\
\hline 1 & Tbl_Barang \\
\hline 2 & Tbl_suplier \\
\hline 3 & Tbl_menu \\
\hline 4 & Tbl_Order_Barang \\
\hline 5 & Tbl_Departemen \\
\hline 6 & Tbl_user \\
\hline 7 & Tbl_chartperbulan \\
\hline 8 & Tbl_charttahunan \\
\hline
\end{tabular}


Tebel 3.0 Struktur Tabel Barang

\begin{tabular}{|c|c|c|c|}
\hline Atribute & Tipe Data & Panjang & Keterangan \\
\hline id & Varchar & 6 & Primary key \\
\hline Nama_barang & Varchar & 100 & Nama barang \\
\hline satuan & int & 10 & satuan \\
\hline jumlah & int & 10 & jumlah \\
\hline Id_supplayer & Int & 10 & Id_supplayer \\
\hline
\end{tabular}

Tebel 4.0 Struktur Tabel Suplier

\begin{tabular}{|c|c|c|c|}
\hline Atribute & Tipe Data & Panjang & Keterangan \\
\hline id & int & 11 & Primary key \\
\hline Nama_supplyer & Varchar & 100 & Nama barang \\
\hline Alamat & Varchar & 100 & merek \\
\hline Jenis_suplayer & Varchar & 20 & jumlah \\
\hline telepon & varchar & 12 & No hp \\
\hline Tanggal_order & timestamp & & Tanggal order \\
\hline
\end{tabular}

Tabel 5.0 Struktur Tabel Menu

\begin{tabular}{|c|c|c|c|}
\hline Atribute & Tipe Data & Panjang & Keterangan \\
\hline$\underline{\text { id }}$ & Int & 11 & Primary key \\
\hline Menu & Varchar & 100 & - \\
\hline url & Varchar & 100 & - \\
\hline level & Int & 20 & - \\
\hline
\end{tabular}

Tabel 6.0 Struktur Tabel Order Barang

\begin{tabular}{|c|c|c|c|}
\hline Atribute & Tipe Data & Panjang & Keterangan \\
\hline$\underline{\text { Id }}$ & varchar & 10 & Primary key \\
\hline Nama_Barang & varchar & 100 & - \\
\hline Merek & varchar & 100 & - \\
\hline Jumlah & varchar & 20 & - \\
\hline Status & Enum & - & True,false, in \\
\hline Tanggal_order & int & 10 & - \\
\hline Id_dep & int & 10 & - \\
\hline
\end{tabular}

Tabel 7.0 Struktur Tabel Order Barang

\begin{tabular}{|c|c|c|c|}
\hline Atribute & Tipe Data & Panjang & Keterangan \\
\hline$\underline{\text { Id }}$ & varchar & 10 & Primary key \\
\hline Nama_Barang & varchar & 100 & - \\
\hline Merek & varchar & 100 & - \\
\hline Jumlah & varchar & 20 & - \\
\hline Status & Enum & - & True,false, in \\
\hline Tanggal_order & int & 10 & - \\
\hline Id_dep & int & 10 & - \\
\hline
\end{tabular}

Tabel 8.0 Struktur Tabel Departemen

\begin{tabular}{|c|c|c|c|}
\hline Atribute & Tipe Data & Panjang & Keterangan \\
\hline id & int & 3 & Primary key \\
\hline Nama_dep & Varchar & 100 & - \\
\hline
\end{tabular}

Tabel 9.0 Struktur Tabel User

\begin{tabular}{|c|c|c|c|}
\hline Atribute & Tipe Data & Panjang & Keterangan \\
\hline id & int & 3 & Primary key \\
\hline Username & Varchar & 100 & - \\
\hline Password & Varchar & 100 & Md5 \\
\hline email & Varchar & 100 & - \\
\hline Id_dep & int & 3 & - \\
\hline Level & int & 10 & - \\
\hline
\end{tabular}

\subsubsection{HIPO}

Adalah perancangan gambaran input output dan proses dari sistem yang telah dibuat: 


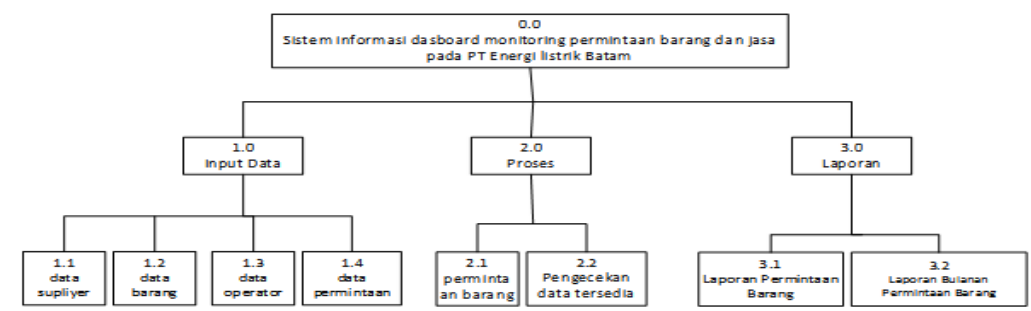

\subsection{Hasil}

1. Tampilan menu Login

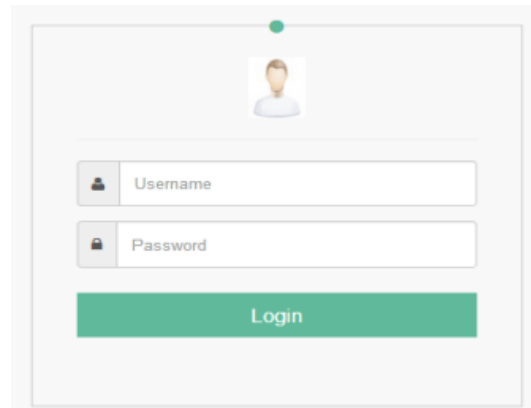

Gambar menu Login

2. Tampilan Web Master atau Super Admin

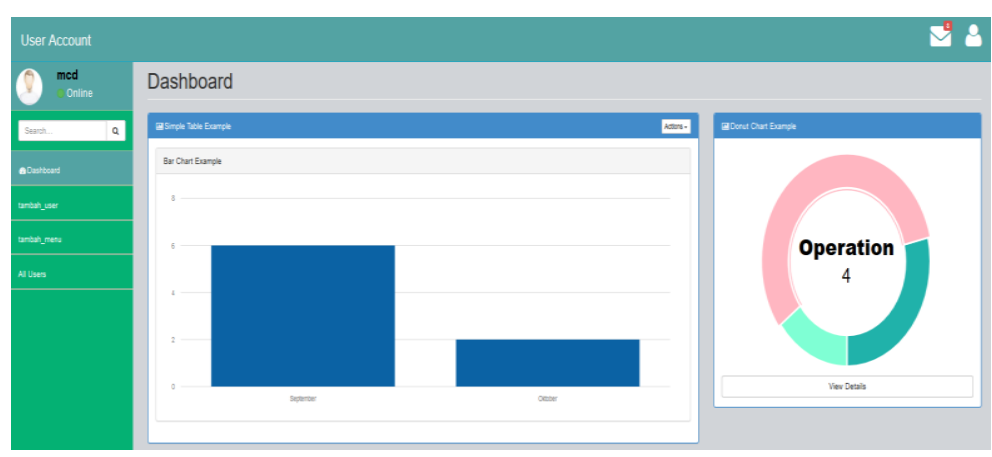

3. Tampilan Detail Dashboard

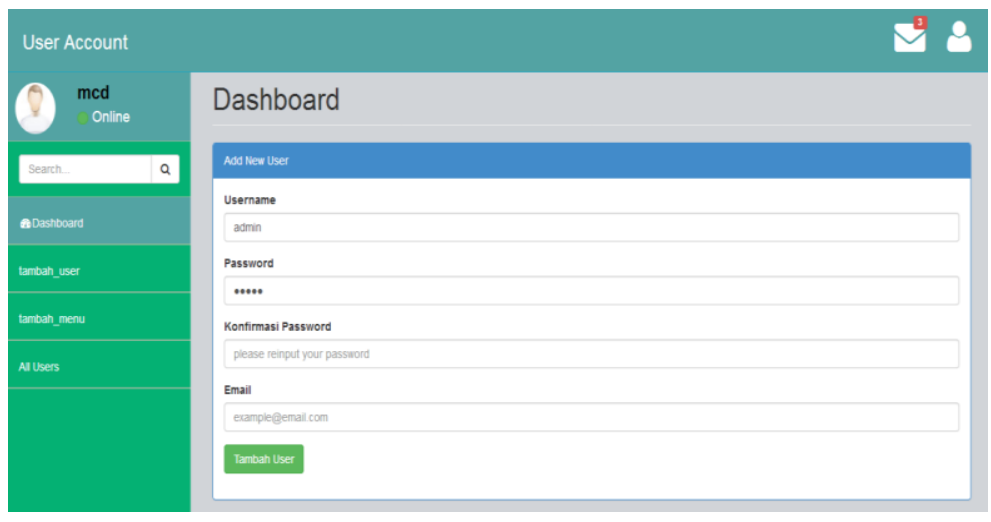

4. Tampilan Input Data User 


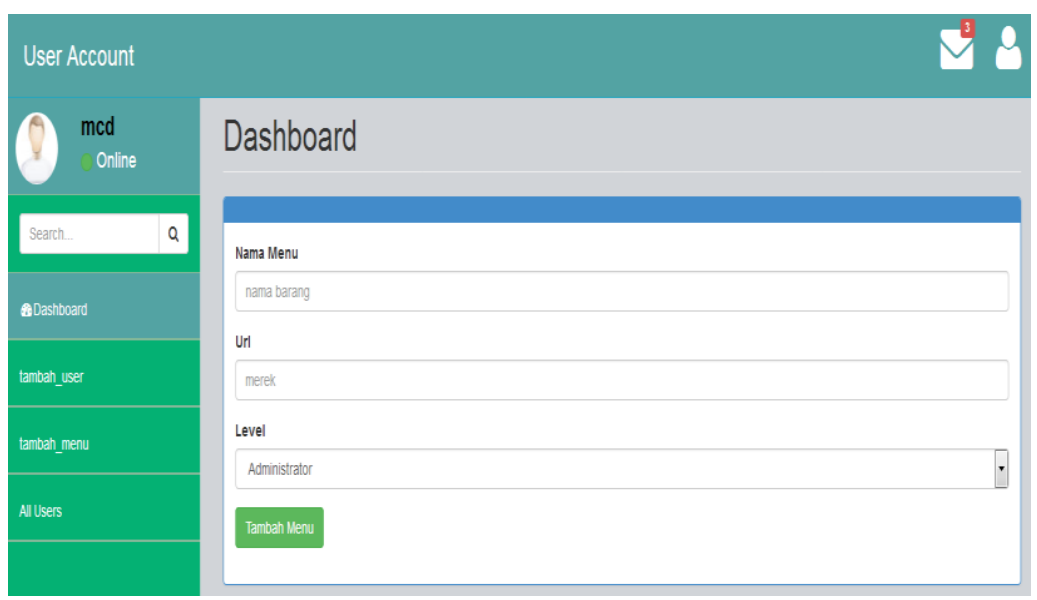

5. Tampilan Data User

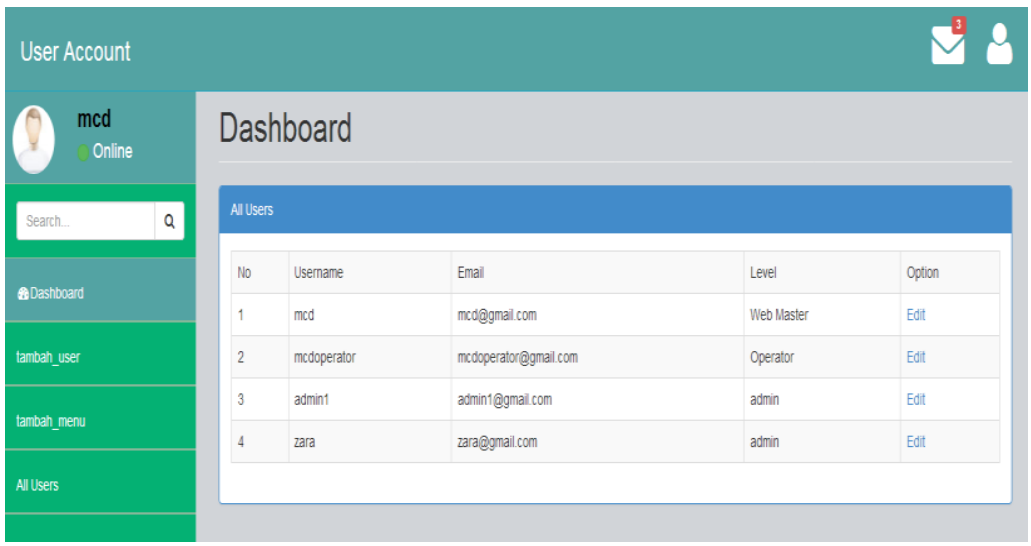

6. Tampilan Data Admin

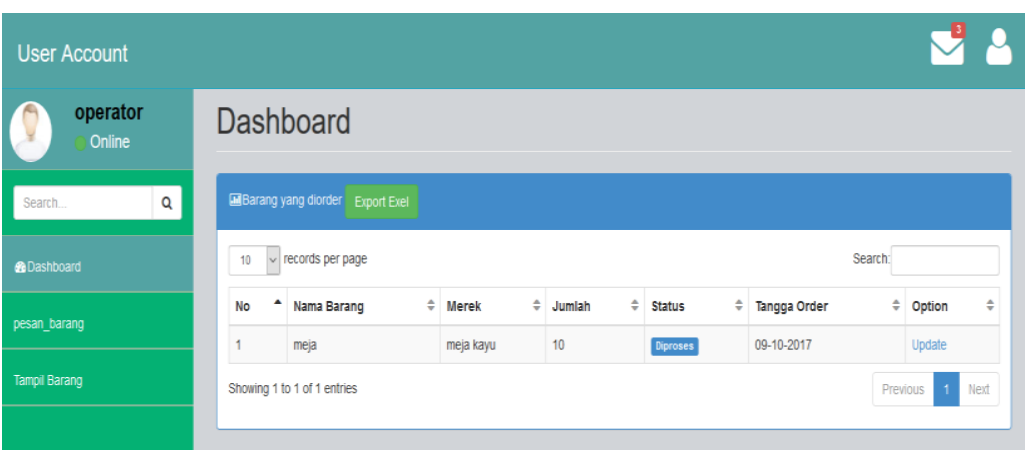

7. Tampilan Operator

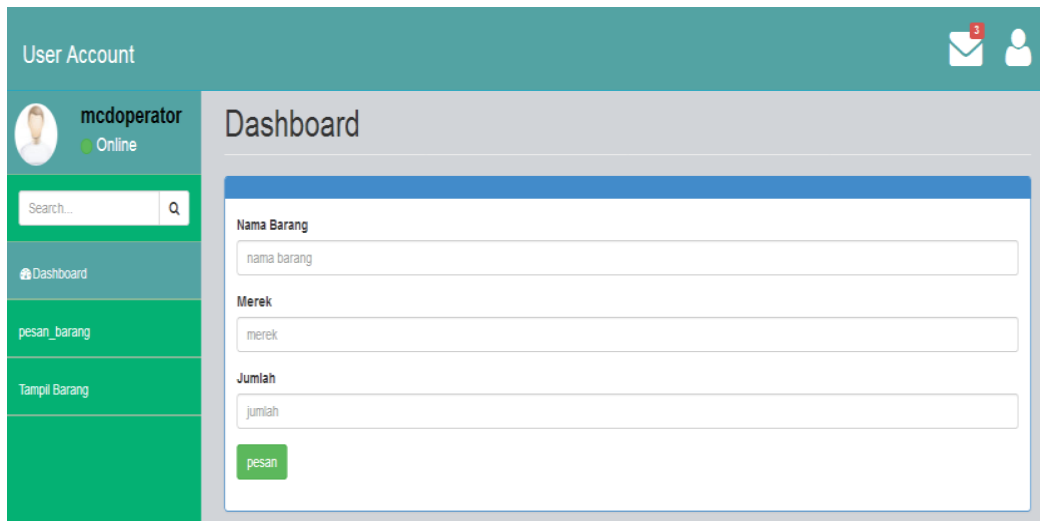




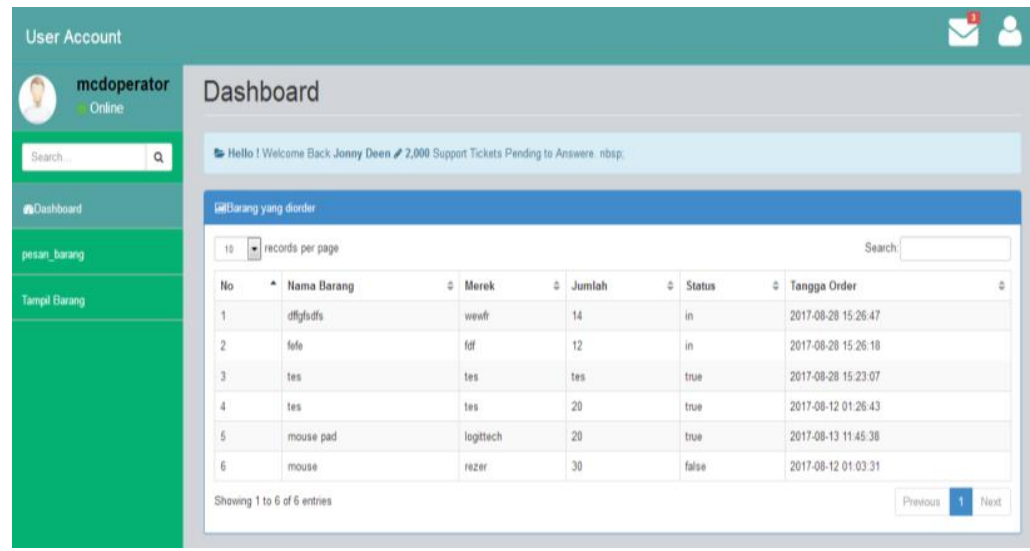

\section{KESIMPULAN}

Mengacu pada rumusan masalah dan tujuan penelitian yang terdapat pada bab satu dan dilanjutkan dengan implementasi pada bab empat maka dapat ditarik beberapa kesimpulan diantranya:

1. Sistem Informasi Dashboard Monitoring Untuk Pengorderan Barang dan Jasa Pada PT Energi Listrik Batam dirancang berbasis web dengan menggunakan Bahasa pemograman PHP dan MySQL sebagai database.

2. Dengan menggunakan Sistem Informasi Dashboard Monitoring Untuk Pengorderan Barang dan Jasa Pada PT Energi Listrik Batam ini akan menghasilkan laporan yang lebih valid, hal ini dikarenakan data yang dimasukan lebih terstruktur dan teralur dengan rapi serta pekerjaan lebih efisien baik waktu dan tenaga karena operator atau admin tidak perlu lagi datang ke pihak terkait untuk meminta data permintaan barang.

\section{SARAN}

Setelah membangun sistem, ada beberapa saran yang harus diterapkan guna pengembangan sistem informasi ini lebih lanjut diantaranya sebagai berikut:

1. Tampilan web diperbaiki supaya lebih user friendly dan pengguna betah untuk menggunakan aplikasi tersebut.

2. Untuk pengembangan selanjutnya aplikasi dibuat responsive dan support mobile android sehingga dapat diakses melalui handphone.

\section{DAFTAR PUSTAKA}

Anwar, S., Efendi, Y., Rustam, R., \& Andrew. (2016). Perancangan Sistem Informasi Pendaftaran Mahasiswa Baru Dan Pengisian Kartu Rencana Studi (KRS) Amik Wahana Mandiri Berbasis Web Mobile. Jurnal Sistem Informasi , Vol.9(1), ISSN: 1979-0767.

Anwar, S., Efendi, Y., \& Dzuhri, A,M. (2016). Perancangan Sistem Informasi Data Trip Lintasan Perhari Cabang Merak Dan Laporan Ke ASDP Berbasis WEB Pada PT. Jemla Ferry. Jurnal Sistem Informasi, Vol.9(1), ISSN: 1979-0767.

Astuti, Puspita Dwi. 2016. Sistem Informasi Penjualan Obat Pada Apotek Jati Farma Arjosari. Speed-Sentra Penelitian Engineering dan Edukasi 3.4. http://ijns.org/journal/index.php/speed/article/viewFile/1217/1205 (diakses 26 Juli 2017).

Aipassa, A.D., Darmawan, I., \& Andreswari, R. (2017). Pembuatan Dashboard Pada Sistem Informasi Pengadaan Barang Dan Jasa Dengan Metode Extreme Programming (Studi Kasus Logistik Universitas Telkom). e-Proceeding of Engineering Sistem Informasi, Vol.4(1), ISSN: 2355-9365. 
Fathansyah. (1999). Basis data. Bandung: Informatika.

Few, Stephen. (2006), Information Dashboard Design, O'Reilly; ISBN: 0-596-10016-7.

Hanif, I, M., \& Fitriani, L. (2016). Perancangan Perangkat Lunak Sistem Informasi Rekam Medis Berbasis Client-Server Studi Kasus Klinik Cipanas. Jurnal STT, Vol.13(1), ISSN: 23027339.

Hakim, I, M., \& Fitriani, L. (2016). Pembuatan Dashboard Berbasis Web Sebagai Sarana Evaluasi Diri Berkala untuk Persiapan Penilaian Akreditasi Berdasarkan Standar Badan Akreditasi Nasional Perguruan Tinggi. Jurnal Sistem Informasi , Vol.1(1), ISSN: 2301-9271.

Hermawan, R., Hidayat, A., \& Utomo., G., V. (2015). Sistem Informasi Penjadwalan Kegiatan Belajar Mengajar Mengajar berbasis Web. Jurnal Evolusi, Vol. 3(2), ISSN: 2338-8161.

Jogiyanto. 2001. Analisis \& Desain Sistem Informasi: pendekatan terstruktur teori dan praktek aplikasi bisnis. Andi, Yogyakarta.

Kadir, A., (2001), Konsep \& Tuntunan praktis Basis Data. Yogyakarta: Andi.

Samantha., Donna., \& Primasari. (2011). Perancangan Sistem Informasi Pada Toko Sahaaba. Undergraduate thesis, UNDIP. Diakses pada tanggal 27 maret 2017 dari http://eprints.undip.ac.id/27077.

Sahupala, A,N \& Rusmawan, U. (2016). Sistem Aplikasi Logistik Dan Purchasing Pada PT Yanmar Indonesia. Jurnal Program Studi Teknik Informatika Vol.1(3), ISSN: 2527-9777.

Sulindawati., \& Fathoni, M. (2010). Pengantar Analisa Perancangan Sistem. Jurnal SAINTIKOM, Vol. 9(2), 2010.

Veza, O. (2017). Perancangan Sistem Informasi Inventory Data Barang Pada Pt. Andalas Berlian Motors (Studi Kasus: PT Andalas Berlian Motors Bukit Tinggi). Jurnal Teknik Ibnu Sina JT-IBSI, 2(2).

Widodo, M,R,R., \& Zainuddin, M. (2016, Desember). Sistem Informasi Dan Pengolahan Data Kursus Mobil Berbasis WEB Dengan Sms Gateway Di Armada Pasuruan. Jurnal Informatika Merdeka Pasuruan. Jurnal teknik Vol.1(2), ISSN: 2503-1945. 